\title{
Rhodotorula Keratitis: A Rarely Encountered Ocular Pathogen
}

\author{
Joseph Giovannini Rick Lee Sean X. Zhang Albert S. Jun \\ Kraig S. Bower
}

Johns Hopkins University, Baltimore, Md., USA

\section{Key Words}

Rhodotorula $\cdot$ Fungal keratitis · Confocal microscopy · Antifungal therapy

\begin{abstract}
Purpose: To describe a case of fungal keratitis involving an atypical organism with confirmatory in vivo confocal microscopy and to review the literature on Rhodotorula keratitis. Methods: Case report and review of the medical literature. Results: A 22-year-old college student was struck in the left eye with a tree branch and subsequently developed pain, redness and photophobia. Upon presentation, visual acuity was 20/200 and there was a large epithelial defect with diffuse stromal inflammation involving the anterior one-third of the cornea. Cultures of the infiltrate were performed for bacterial, viral and fungal organisms that resulted in a positive culture for Rhodotorula mucilaginosa. Fungal elements were confirmed in vivo by confocal microscopy. The patient was treated with voriconazole initially and had amphotericin added once Rhodotorula infection was confirmed. The patient responded well clinically, and one month after therapy was initiated, the corneal infiltrate had resolved leaving mild anterior stromal haze. Upon completion of therapy at three months, the patient was asymptomatic, had a clear cornea and had a best corrected visual acuity of 20/20 in the involved eye. There was no measurable change in his manifest refraction. Conclusions: Prior cases of Rhodotorula keratitis most often required surgical intervention and were associated with poor outcomes. This case shows that Rhodotorula keratitis can be successfully treated with topical antifungal agents if diagnosed early and appropriate treatment is initiated promptly. We report the first case of Rhodotorula keratitis confirmed by in vivo confocal microscopy. This is also the first description of pseudomycelium formation that has not been previously described in vivo, a morphological structure that this organism rarely demonstrates. Finally, this case shows that confocal microscopy may aid in the early diagnosis and management of fungal keratitis involving this rare but potentially damaging organism.
\end{abstract}


Giovannini et al.: Rhodotorula Keratitis: A Rarely Encountered Ocular Pathogen

\section{Introduction}

Most fungal infections of the cornea occur either in the setting of trauma or in association with preexisting corneal disease actively under treatment with antibiotics or corticosteroids. When ocular trauma occurs, it often involves some type of vegetable matter. Antibiotics are known to change the indigenous ocular flora in a way that allows mycotic organisms to more easily flourish in the absence of the normal inhibitory action of bacteria. Finally, corticosteroids are well known to suppress immune defenses, thus increasing susceptibility to infections. Rhodotorula is a yeast organism that is common in the environment but rarely the cause of human disease. A search of the literature reveals that Rhodotorula can be considered an emerging pathogen with an increasing number and variety of disease processes having been attributed to this organism over the last few decades [1]. Although Rhodotorula is of low virulence, it is an opportunistic pathogen that can affect both immunosuppressed, as well as immunologically competent humans under the appropriate circumstances [1]. Fungemia is the most common manifestation by far, with over 100 cases documented in the medical literature. Rhodotorula has also been shown to be the causative agent in cases of endocarditis, peritonitis, meningitis as well as infections of the skin, prosthetic joints and the eye. Of all these other areas, ocular infections are the most common site of Rhodotorula disease, being second only to sepsis. At present, there are 15 cases of eye infections in the medical literature [2-17]. We believe this is the first case report of Rhodotorula mucilaginosa keratitis in the US. In addition, this is the first demonstration of in vivo confocal imaging of R. mucilaginosa.

\section{Case Report}

A 22-year-old gentleman presented to our clinic reporting that he was struck in his left eye with a tree branch two days previously. Immediately after the injury he vigorously flushed his eye out with tap water, but the next day he continued to have eye pain and poor vision and reported to the local urgent care facility. He was diagnosed with a corneal abrasion, started on sulfacetamide drops every two hours, and advised to follow-up with an ophthalmologist. He was seen in our clinic for a follow-up evaluation the next day. Upon examination he was found to have a best-corrected visual acuity (BCVA) of 20/200 and a $2 \times$ $3 \mathrm{~mm}$ epithelial defect just below the corneal apex. The defect was noteworthy because it was associated with a very prominent infiltrate of the anterior corneal stroma. Cultures of the cornea were performed for bacterial, viral and fungal organisms, and the patient was started on moxifloxacin eye drops every hour with directions to follow-up in 24 hours.

The next day there was no significant change in the patient's condition. He was seen again 48 hours later and the epithelial defect was almost healed except for the appearance of moderate punctate epithelial erosions in the distribution of the original abrasion as well as the dense stromal cellular infiltrate. Although the BCVA had improved to 20/30, the stromal infiltrate persisted and involved the anterior one-third of the cornea. Cultures had become positive for germ tube-negative yeast (fig. 1). There was no consolidation of the infiltrate, abscess formation or ulceration. Furthermore, the deep cornea remained uninvolved and there was no anterior chamber reaction. The patient was immediately started on voriconazole $1 \%$ drops every hour. Seventy-two hours later, eight days after the initial injury, the patient was examined again and his vision had improved to 20/20 (BCVA) and the epithelial defect had healed. Still, a cellular infiltrate remained in the anterior one-third of the corneal stroma, though it was concentrated more centrally with peripheral clearing (fig. 2a, b). The 
Giovannini et al.: Rhodotorula Keratitis: A Rarely Encountered Ocular Pathogen

patient was sent for confocal microscopy. Confocal images (fig. 3) revealed both round and dumbbell shaped structures suggestive of budding yeast forms as well as extensive branching structures resembling hyphae or pseudohyphae structures. Twelve days after the initial injury the patient was seen again and the infiltrate seemed to have improved and vision remained stable. By this visit the fungal culture was identified as R. mucilaginosa by DNA sequencing, and after a review of the literature suggested that amphotericin B would provide good coverage [1], topical amphotericin B $0.15 \%$ was added to his treatment schedule. One week later the patient returned and the infiltrate seemed to be nearly resolved, but a residual haze of the anterior corneal stroma persisted. One month after the initial injury only a faint stromal haze remained. Repeat confocal microscopy at this time (fig. 4) demonstrated that the inflammatory process had impressively resolved leaving what appeared to be residual fragments of the previously seen branching structures that had lost their tubular architecture. The patient was continued on amphotericin and voriconazole for a total course of three months at which time medications were discontinued with apparent full resolution of the infectious process. A full three months of treatment was administered because it is known that fungal infections require prolonged therapy [18]. The patient has continued to do well.

\section{Discussion}

We present the case of a young and healthy male college student with rapidly progressive corneal inflammation after minor vegetable matter trauma. He presented early before any deep stromal invasion or stromal ulceration could occur. Confocal findings were consistent with fungal keratitis and he was started early on topical voriconazole. When cultures were positive for $R$. mucilaginosa, amphotericin B was added to his topical antifungal regimen. In vitro susceptibility testing was performed showing low minimum inhibitory concentration (MIC) with amphotericin B, but relatively high MIC with voriconazole. The patient responded well clinically, and at three months after presentation he was asymptomatic with 20/20 corrected visual acuity and a clear cornea.

\section{Review of the Literature}

The exact incidence of fungal keratitis in the US is not known [19]. Similarly, a PubMed search could not establish the proportion of infectious keratitis that is fungal within the US. In Asia, the proportion of culture-proven fungal keratitis has been reported to be over $50 \%$ in some instances, thereby exceeding the rate of bacterial keratitis [19]. In the US and other temperate climates, mycotic keratitis is fairly unusual but is still commonly seen in tertiary referral centers like our own, and the medical literature shows that it accounts for significant morbidity across the globe. A combination of factors may contribute to this, including the trend for most ophthalmologists to treat empirically for bacterial pathogens, delayed identification of the organism, and poor availability and only fair efficacy of ophthalmic antifungal medications.

The genus Rhodotorula includes eight species, of which $R$. mucilaginosa, $R$. glutinis and $R$. minutae are known to cause human disease [1]. This yeast is common in the environment but very uncommon in the normal ocular flora [2]. It produces unique red-orange colonies when grown in culture and has a strong affinity for plastic [1]. This explains its predilection for causing sepsis in patients that have chronic indwelling catheters. Ocular Rhodotorula 
infections have been reported in the form of keratitis [2-11], scleritis [12], dacryosystitis [6] and endophthalmitis [13-16]. The first reported case of Rhodotorula keratitis was by Wawer in 1965 [3]. Since then, nine additional reports of keratitis have been published (table 1). Two of those reports are apparently the same case [2,20], giving a total of 9 cases of Rhodotorula keratitis in the published literature to date. Although the affected individuals were generally healthy, most of them had associated trauma (six cases) and three had prior corneal surgery. Seven patients required some form of surgical intervention to achieve resolution, four of them having penetrating keratoplasties, two needing repeat penetrating keratoplasty, and one requiring removal of a prior lamellar graft.

Confocal microscopy has shown itself to be a useful adjunct in the diagnosis of these infections. Cultures are positive only about $60 \%$ of the time and may take weeks to become positive. In the present case we used confocal microscopy to confirm the results of cultures that had already been confirmed as R. mucilaginosa by DNA sequencing. Confocal microscopy revealed that both round and dumbbell shaped structures of the correct size and morphology were present (fig. 4). These were suggestive of budding yeast forms as well as tubular branching structures resembling hyphae or pseudohyphae. Rhodotorula species do not normally form branching structures when they grow on laboratory culture media. However, under certain conditions, such as in a biofilm, this organism can form extensive pseudomycelium [17]. Furthermore, a case of a corneal button removed for Rhodotorula infection in Italy in 1992 demonstrated that pseudomycelium, although not seen in vitro, is a morphology that can manifest in corneal infections [4]. To our knowledge, Rhodotorula pseudomycelium seen in vivo has not been reported.

Of note, there are no established breakpoints to interpret susceptibility testing results for this yeast. In 2005, Gomez-Lopez et al. [21] performed in vitro antifungal susceptibility testing of 29 clinical Rhodotorula isolates ( 25 R. mucilaginosa and $4 R$. glutinis). Their results showed that amphotericin $B$ and flucytosine had the highest in vitro activity against Rhodotorula spp., and fluconazole had the lowest activity, with itraconazole, voriconazole, and ravuconazole showing intermediate activity. In addition, the authors reviewed nine reports (a total of 102 Rhodotorula organisms) and found similar results. Presently, none of the reported cases were isolated from ocular infection. Only two previous Rhodotorula case reports tested antifungal susceptibility. Rajmane et al. [10] found MICs for fluconazole and itraconazole were very high $\left(\mathrm{MIC}_{90}=64 \mu \mathrm{g} / \mathrm{ml}\right)$ and amphotericin B showed the lowest MIC $\left(\mathrm{MIC}_{90}=1 \mu \mathrm{g} / \mathrm{ml}\right)$. Saha et al. [11] found maximum sensitivity to voriconazole, intermediate activity to amphotericin B and natamycin, and resistance to itraconazole and fluconazole. The most recent large review from the European Society of Clinical Microbiology and Infectious Diseases [18] recommends that amphotericin B be the treatment of choice in Rhodotorula infections. In our keratitis case Rhodotorula had low MICs to both amphotericin $B$ and flucytosine while showing relatively high MIC to voriconazole.

In summary we report the case of an unusual keratitis in a young healthy patient that we believe to be the first report of Rhodotorula keratitis in the US. Our patient responded to topical medical treatment with good results as opposed to cases in the literature that required surgery or had poor visual outcomes. This is the first reported case of $R$. mucilaginosa keratitis with in vivo confocal microscopy that demonstrates the organism in an unusual morphology that has not been seen before in vivo. 
Giovannini et al.: Rhodotorula Keratitis: A Rarely Encountered Ocular Pathogen

\section{Disclosure Statement}

The authors have no financial interest in any product, drug, instrument or equipment discussed in this paper. There was no financial support, public or private, used to fund this study.

\section{References}

1 Wirth F, Goldani LZ: Epidemiology of Rhodotorula: an emerging pathogen. Interdiscip Perspect Infect Dis 2012;2012:465717.

-2 Romano A, Segal E, Ben-Tovim T: Epithelial keratitis due to rhodotorula. Ophthalmologica 1973;166:353359.

-3 Wawer P: [Recovery of vision after keratoplasty used in the treatment of Rhodotorula infection of the cornea]. Klin Oczna 1965;35:451-453. Polish.

4 Guerra R, Cavallini GM, Longanesi L, Casolari C, Bertoli G, Rivasi F, Fabio U: Rhodotorula glutinis keratitis. Int Ophthalmol 1992;16:187-190.

5 Casolari C, Nanetti A, Cavallini GM, Rivasi F, Fabio U, Mazzoni A: Keratomycosis with an unusual etiology (Rhodotorula glutinis): a case report. Microbiologica 1992;15:83-87.

6 Muralidhar S, Sulthana CM: Rhodotorula causing chronic dacryocystitis: a case report. Indian J Ophthalmol 1995;43:196-198.

7 Panda A, Pushker N, Nainiwal S, Satpathy G, Nayak N: Rhodotorula sp. infection in corneal interface following lamellar keratoplasty - a case report. Acta Ophthalmol Scand 1999;77:227-228.

8 Bawazeer AM, Hodge WG: Rhodotorula infection in a corneal graft following penetrating keratoplasty. Can J Ophthalmol 2003;38:225-227.

-9 Lifshitz T, Levy J: Rhodotorula rubra keratitis and melting after repeated penetrating keratoplasty. Eur J Ophthalmol 2005;15:135-137.

10 Rajmane VS, Rajmane ST, Ghatole MP: Rhodotorula species infection in traumatic keratitis - a case report. Diagn Microbiol Infect Dis 2011;71:428-429.

11 Saha S, Sengupta J, Chatterjee D, Banerjee D: Rhodotorula mucilaginosa keratitis: A rare fungus from Eastern India. Indian J Ophthalmol 2014;62:341-344.

12 Pradhan ZS, Jacob P: Management of Rhodotorula scleritis. Eye (Lond) 2012;26:1587.

12 Dorey MW, Brownstein S, Kertes PJ, Gilberg SM, Toye B: Rhodotorula glutinis endophthalmitis. Can J Ophthalmol 2002;37:416-418.

14 Merkur AB, Hodge WG: Rhodotorula rubra endophthalmitis in an HIV positive patient. Br J Ophthalmol 2002;86:1444-1445.

15 Pinna A, Carta F, Zanetti S, Sanna S, Sechi LA: Endogenous Rhodotorula minuta and Candida albicans endophthalmitis in an injecting drug user. Br J Ophthalmol 2001;85:759.

16 Gregory JK, Haller JA: Chronic postoperative Rhodotorula endophthalmitis. Arch Ophthalmol 1992;110:1686-1687.

17 Bozena DK, Magdalena KS: Pseudomycelium forming Rhodotorula - unusual picture of biofilm. Mikolgia Lekarska 2011;18:74-78.

18 Arendrup MC, Boekhout T, Akova M, Meis JF, Cornely OA, Lortholary O: ESCMID and ECMM joint clinical guidelines for the diagnosis and management of rare invasive yeast infections. Clin Microbiol Infect 2014;20(suppl 3):76-98.

19 Thomas PA, Kaliamurthy J: Mycotic keratitis: epidemiology, diagnosis and management. Clin Microbiol Infect 2013;19:210-220.

-20 Segal E, Romano A, Eylan E, Stein R, Ben-Tovim T: Rhodotorula rubra - cause of eye infection. Mykosen 1975;18:107-111.

21 Gomez-Lopez A, Mellado E, Rodriguez-Tudela JL, Cuenca-Estrella M: Susceptibility profile of 29 clinical isolates of Rhodotorula spp. and literature review. J Antimicrob Chemother 2005;55:312-316. 
Table 1. Corneal infections caused by Rhodotorula species

\begin{tabular}{|c|c|c|c|c|c|c|c|c|}
\hline $\begin{array}{l}\text { First author, } \\
\text { year, } \\
\text { location }\end{array}$ & $\begin{array}{l}\text { Gen- } \\
\text { der/ } \\
\text { age }\end{array}$ & $\begin{array}{l}\text { Systemic } \\
\text { disease }\end{array}$ & $\begin{array}{l}\text { Corneal } \\
\text { disease }\end{array}$ & $\begin{array}{l}\text { Clinical } \\
\text { presentation }\end{array}$ & $\begin{array}{l}\text { Initial } \\
\text { vision }\end{array}$ & Organism (source) & Treatment & Outcome \\
\hline $\begin{array}{l}\text { Wawer, } \\
\text { 1965, } \\
\text { Poland [3] }\end{array}$ & & & & & $\begin{array}{l}5 / 25 \\
(20 / 100)\end{array}$ & Rhodotorula spp. & $\begin{array}{l}\text { Penetrating } \\
\text { keratoplasty }\end{array}$ & $\begin{array}{l}\text { Clear graft; vision } \\
5 / 8(20 / 32) \text { at } 3 \\
\text { months }\end{array}$ \\
\hline $\begin{array}{l}\text { Romano, } \\
\text { 1973, } \\
\text { Israel [2] }\end{array}$ & $\mathrm{F} / 29$ & $\begin{array}{l}\text { 'exhausted, } \\
\text { anemic and } \\
\text { asthenic' }\end{array}$ & None & $\begin{array}{l}\text { Multifocal bilateral } \\
\text { epithelial and } \\
\text { anterior stromal } \\
\text { infiltrates }\end{array}$ & $\begin{array}{l}1 / 60 \text { with } \\
\text { eccentric } \\
\text { fixation OD; } \\
6 / 24 \text { OS }\end{array}$ & $\begin{array}{l}\text { R. mucilaginosa and } \\
\text { Comamonas terrigena } \\
\text { (ocular surface) }\end{array}$ & $\begin{array}{l}\text { Topical } \\
\text { amphotericin B and } \\
\text { mycostatin; oral } \\
\text { mycostatin }\end{array}$ & $\begin{array}{l}\text { 'quiet eyes' with } \\
20 / 20 \text { vision at } 3 \\
\text { month post } \\
\text { treatment }\end{array}$ \\
\hline $\begin{array}{l}\text { Guerra, } \\
1992, \\
\text { Italy [4] }\end{array}$ & $\mathrm{M} / 40$ & $\begin{array}{l}\text { None } \\
\text { reported }\end{array}$ & $\begin{array}{l}\text { Trauma (twig) } \\
7 \text { months prior }\end{array}$ & $\begin{array}{l}2.5 \mathrm{~mm} \\
\text { subepithelial } \\
\text { infiltrate }\end{array}$ & $20 / 40$ & $\begin{array}{l}\text { R. glutinis (corneal } \\
\text { button), corneal } \\
\text { scrapings negative }\end{array}$ & $\begin{array}{l}\text { Penetrating } \\
\text { keratoplasty }\end{array}$ & $\begin{array}{l}\text { Clear graft, } 20 / 20 \text { at } \\
5 \text { months after } \\
\text { surgery }\end{array}$ \\
\hline $\begin{array}{l}\text { Casolari, } \\
1992, \\
\text { Italy [5] }\end{array}$ & $\mathrm{M} / 40$ & $\begin{array}{l}\text { None } \\
\text { reported }\end{array}$ & $\begin{array}{l}\text { Foreign body } \\
\text { trauma } \\
5 \text { months prior }\end{array}$ & $\begin{array}{l}\text { Dense, deep } \\
\text { stromal keratitis } \\
\text { extending to } \\
\text { endothelium }\end{array}$ & $\begin{array}{l}4 / 10 \\
(20 / 50)\end{array}$ & $\begin{array}{l}\text { R. glutinis (corneal } \\
\text { button) }\end{array}$ & $\begin{array}{l}\text { Penetrating } \\
\text { keratoplasty }\end{array}$ & $\begin{array}{l}\text { Clear graft with } \\
\text { visual acuity } 10 / 10 \\
(20 / 20) \text { at } 5 \text { months } \\
\text { after surgery }\end{array}$ \\
\hline $\begin{array}{l}\text { Muralidhar, } \\
\text { 1995, } \\
\text { India [6] }\end{array}$ & $\mathrm{M} / 50$ & $\begin{array}{l}\text { None } \\
\text { reported }\end{array}$ & $\begin{array}{l}\text { Agricultural } \\
\text { trauma } \\
\text { (paddy stick) } \\
1 \text { month prior }\end{array}$ & $\begin{array}{l}7-8 \mathrm{~mm} \text { central } \\
\text { ulcer with } \\
\text { hypopion; } \\
\text { dacryocystitis }\end{array}$ & $\begin{array}{l}\text { Light } \\
\text { perception }\end{array}$ & $\begin{array}{l}\text { R. rubra (corneal } \\
\text { scrapings, lacrimal } \\
\text { discharge, lacrimal sac } \\
\text { after } \\
\text { dacryocystorhinostomy) }\end{array}$ & $\begin{array}{l}\text { Topical } \\
\text { chloramphenicol, } \\
\text { miconazole and } \\
\text { natamycin }\end{array}$ & $\begin{array}{l}\text { Counting fingers } \\
\text { vision and lost to } \\
\text { follow-up }\end{array}$ \\
\hline $\begin{array}{l}\text { Panda, } \\
\text { 1999, } \\
\text { India [7] }\end{array}$ & $\mathrm{M} / 55$ & $\begin{array}{l}\text { None } \\
\text { reported }\end{array}$ & $\begin{array}{l}\text { Lamellar } \\
\text { keratoplasty } \\
5 \text { days prior }\end{array}$ & $\begin{array}{l}\text { Lamellar keratitis } \\
\text { and suture abscess }\end{array}$ & $\begin{array}{l}20 / 120 \\
\text { (after } \\
\text { lamellar } \\
\text { keratoplasty) }\end{array}$ & $\begin{array}{l}\text { Rhodotorula spp. } \\
\text { (interface biopsy) }\end{array}$ & $\begin{array}{l}\text { Surgical removal of } \\
\text { lamellar graft; } \\
\text { topical natamycin } \\
\text { and amphotericin B }\end{array}$ & $\begin{array}{l}\text { 'fully controlled' with } \\
\text { vascularized corneal } \\
\text { opacity at } 1 \text { month } \\
\text { after surgery }\end{array}$ \\
\hline $\begin{array}{l}\text { Bawazeer, } \\
\text { 2003, } \\
\text { Canada } \\
\text { (or Saudi } \\
\text { Arabia?) [8] }\end{array}$ & $\mathrm{F} / 53$ & $\begin{array}{l}\text { None } \\
\text { reported }\end{array}$ & $\begin{array}{l}\text { Penetrating } \\
\text { keratoplasty } \\
1 \text { year prior }\end{array}$ & $\begin{array}{l}\text { Epithelial defect, } \\
\text { large infiltrate with } \\
\text { numerous deep } \\
\text { satellite infiltrates } \\
\text { and diffuse corneal } \\
\text { edema }\end{array}$ & $\begin{array}{l}\text { Hand } \\
\text { motion }\end{array}$ & $\begin{array}{l}\text { Rhodotorula spp. } \\
\text { (corneal button), } \\
\text { corneal scrapings } \\
\text { negative }\end{array}$ & $\begin{array}{l}\text { Penetrating } \\
\text { keratoplasty; topical } \\
\text { amphotericin B }\end{array}$ & $\begin{array}{l}\text { Clear graft with } \\
20 / 400 \text { visual acuity } \\
\text { at } 6 \text { months after } \\
\text { surgery }\end{array}$ \\
\hline $\begin{array}{l}\text { Lifshitz, } \\
2005, \\
\text { Israel [9] }\end{array}$ & $\mathrm{M} / 78$ & $\begin{array}{l}\text { 'debilitated', } \\
\text { uncontrolled } \\
\text { diabetes, } \\
\text { renal failure }\end{array}$ & $\begin{array}{l}\text { Penetrating } \\
\text { keratoplasty } \\
1 \text { month prior }\end{array}$ & $\begin{array}{l}\text { Deep stromal } \\
\text { infiltrate with } \\
\text { melting and } \\
\text { hypopion } 1 \text { month } \\
\text { after second } \\
\text { penetrating } \\
\text { keratoplasty }\end{array}$ & $\begin{array}{l}\text { Hand } \\
\text { motion }\end{array}$ & $\begin{array}{l}\text { R. rubra (corneal } \\
\text { scrapings) }\end{array}$ & $\begin{array}{l}\text { Penetrating } \\
\text { keratoplasty; } \\
\text { intravenous and } \\
\text { topical } \\
\text { amphotericin B }\end{array}$ & $\begin{array}{l}\text { Clear graft, counting } \\
\text { fingers vision at } 6 \\
\text { months after surgery }\end{array}$ \\
\hline $\begin{array}{l}\text { Rajmane, } \\
2011, \\
\text { India [10] }\end{array}$ & $\mathrm{M} / 40$ & $\begin{array}{l}\text { None } \\
\text { reported }\end{array}$ & $\begin{array}{l}\text { Agricultural } \\
\text { trauma } \\
\text { (sugarcane } \\
\text { leaf) } \\
6 \text { days prior }\end{array}$ & $\begin{array}{l}\text { Marked } \\
\text { conjunctivitis, } \\
\text { corneal edema, and } \\
4 \times 3 \mathrm{~mm} \text { infiltrate }\end{array}$ & $\begin{array}{l}\text { Not } \\
\text { recorded }\end{array}$ & $\begin{array}{l}\text { Rhodotorula spp. } \\
\text { (corneal scrapings) }\end{array}$ & $\begin{array}{l}\text { Topical } \\
\text { amphotericin B }\end{array}$ & $\begin{array}{l}\text { Infiltrate regressed } \\
\text { leaving a } \\
\text { vascularized corneal } \\
\text { opacity within one } \\
\text { month }\end{array}$ \\
\hline $\begin{array}{l}\text { Saha, } \\
2013, \\
\text { India [11] }\end{array}$ & $\mathrm{M} / 30$ & $\begin{array}{l}\text { None } \\
\text { reported }\end{array}$ & $\begin{array}{l}\text { 'fall of paint' } \\
14 \text { days prior }\end{array}$ & $\begin{array}{l}\text { Full-thickness } 9.8 \times \\
8.2 \text { mm infiltrate } \\
\text { with hypopion }\end{array}$ & $\begin{array}{l}\text { Light } \\
\text { perception }\end{array}$ & $\begin{array}{l}\text { R. mucilaginosa } \\
\text { (corneal button) }\end{array}$ & $\begin{array}{l}\text { Penetrating } \\
\text { keratoplasty; topical } \\
\text { amphotericin B and } \\
\text { natamycin and oral } \\
\text { itraconazole; topical } \\
\text { voriconazole, and } \\
\text { voriconazole } \\
\text { anterior chamber } \\
\text { lavage }\end{array}$ & $\begin{array}{l}\text { 'resolution of the } \\
\text { infection and } \\
\text { subsequently graft } \\
\text { failure at the end of } 3 \\
\text { months' }\end{array}$ \\
\hline
\end{tabular}


Case Reports in

Ophthalmology
Case Rep Ophthalmol 2014;5:302-310

DOI: $10.1159 / 000365986$

Whyw.karger.com/cop

Giovannini et al.: Rhodotorula Keratitis: A Rarely Encountered Ocular Pathogen

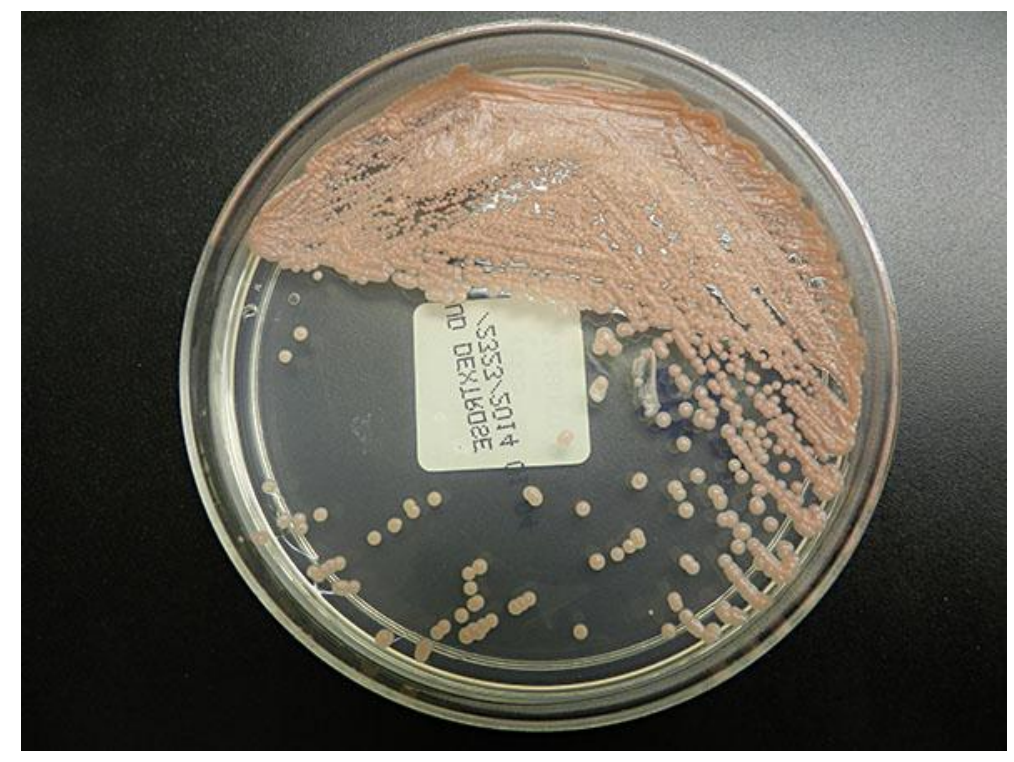

Fig. 1. Distinctive orange-red colonies of Rhodotorula from our Sabouraud agar culture. 
Case Reports in

Ophthalmology
Case Rep Ophthalmol 2014;5:302-310

DOI: $10.1159 / 000365986$

Giovannini et al.: Rhodotorula Keratitis: A Rarely Encountered Ocular Pathogen

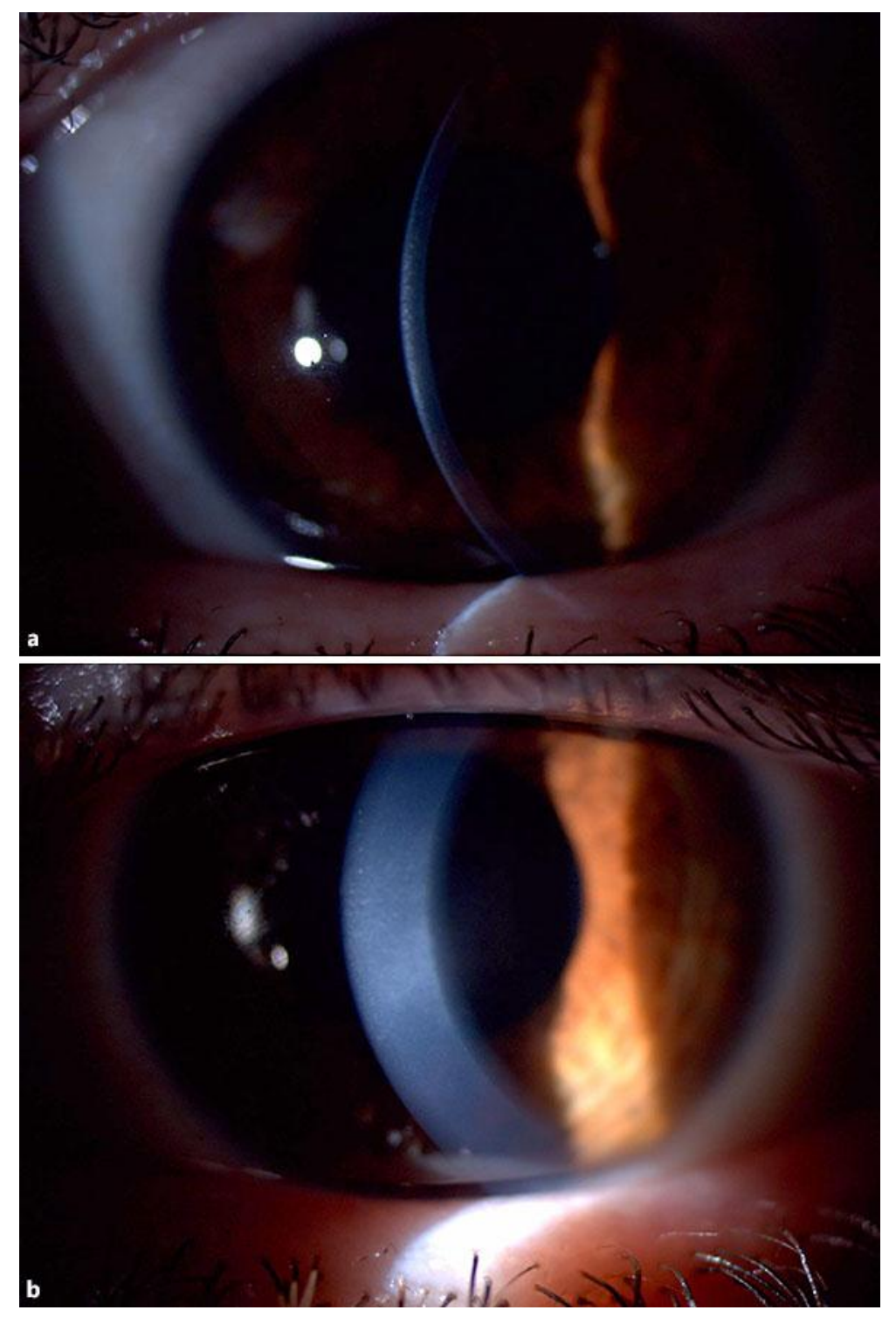

Fig. 2. a, b Appearance of anterior stromal infiltrate on day eight after the injury. 


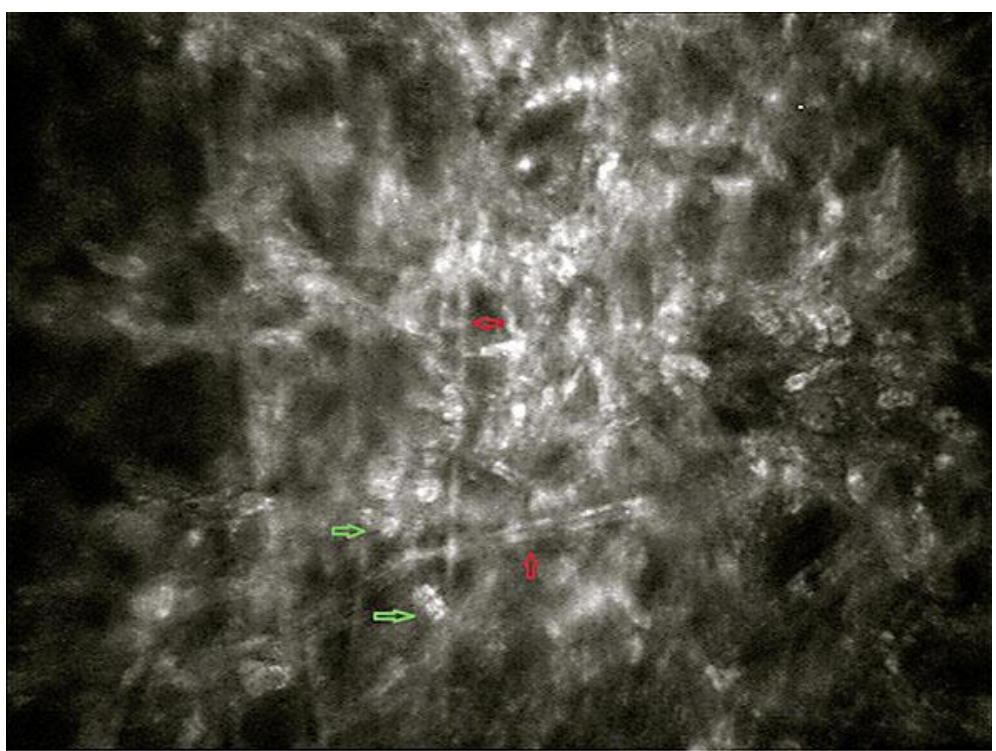

Fig. 3. In vivo confocal microscopy showing a dense inflammatory process on day eight. Green arrows indicate budding yeast forms. Red arrows indicate tubular structures consistent with pseudomycelium (also known as pseudohyphae).

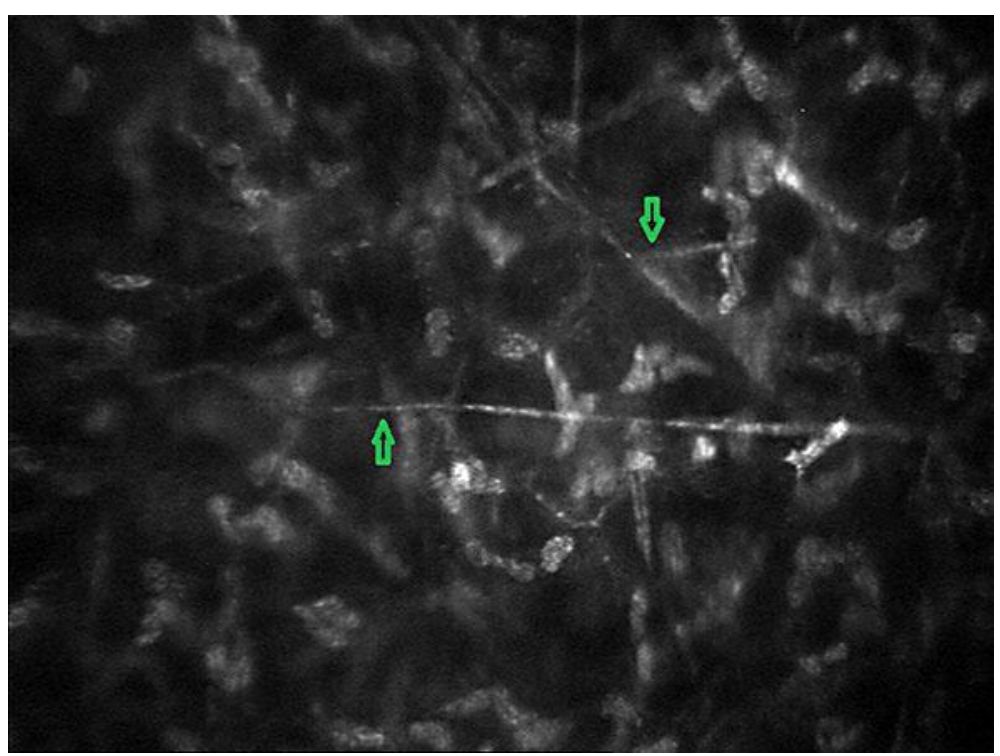

Fig. 4. In vivo confocal microscopy showing resolution of the inflammatory process 30 days after the injury. Green arrows show what appears to be fragmentation of the formerly seen tubular structures. 